\title{
Degradation of RNA in Escherichia coli Induced by Sodium Chloride
}

\author{
Kazutoshi Ito, Kazuo NaKamURA, Kazuo IZAKI \\ and Hajime TAKAHASHI \\ The Department of Agricultural Chemistry, Faculty of Agriculture, \\ Tohoku University, Sendai 980 \\ Received August 13, 1976
}

\begin{abstract}
The degradation of RNA was induced during incubation of Escherichia coli cells in $0.01 \mathrm{M}$ Tris buffer containing $0.15 \mathrm{M}$ sodium chloride $(0.15 \mathrm{M} \mathrm{NaCl}$-Tris buffer). After incubation in $0.15 \mathrm{M} \mathrm{NaCl}$-Tris buffer for $120 \mathrm{~min}$, approximately $50 \%$ of RNA was lost from the acid insoluble fraction. When magnesium $(50 \mathrm{~mm})$ was added to $0.15 \mathrm{M} \mathrm{NaCl}$-Tris buffer, the degradation of RNA was completely prevented. When crude ribosomes, which were prepared by sonic disruption of the cells, were incubated in $0.15 \mathrm{M} \mathrm{NaCl}$-Tris buffer, RNA was rapidly degraded but the addition of magnesium $(5 \mathrm{mM})$ again prevented the degradation of RNA. 3'-Mononucleotides, but not $5^{\prime}$-mononucleotides, were determined as the main degradation products of cellular RNA. When E. coli Q 13, a mutant deficient in ribonuclease (RNase) I, was treated in a similar fashion, no degradation of RNA occurred. These results suggest that the degradation of RNA during incubation in $0.15 \mathrm{M} \mathrm{NaCl}-\mathrm{Tr}$ is buffer is due to the enzymatic action of RNase $\mathrm{I}$.
\end{abstract}

In a previous paper, it was proposed that the saline-sensitive phenomenon in Escherichia coli should be called as sodium chlorideosmotic shock since injuries of cells induced by incubation in sodium chloride were recoverable but those induced by the following dilution in dilute salt solution were no longer recoverable as determined by viabilities. ${ }^{1} \quad$ Previous studies from this laboratory showed that the release of ultraviolet (UV)-absorbing materials occurred during incubation in $0.15 \mathrm{M} \mathrm{NaCl}$-Tris buffer and the release was prevented by the addition of magnesium to $0.15 \mathrm{M} \mathrm{NaCl}$-Tris buffer. ${ }^{2,3)}$ These authors observed the loss of magnesium from the cells during incubation in $0.15 \mathrm{M} \mathrm{NaCl}$-Tris buffer. A similar protective effect of magnesium was observed in the cold shock of $E$. coli by Sato et al. ${ }^{4 \sim 7}$ ) They concluded that the loss of magnesium from cells induced by the cold shock caused instability of deoxyribonucleic acid (DNA) which was supposed to be one of the lethal damages for the cells. It has been reported by MacCarthy, Mizuno et al. and Neu et al. that the ribosomal

\footnotetext{
A part of this paper was presented at the Annual Meeting of the Agricultural Chemical Society of Japan on April, 1974 held in Tokyo.
}

ribonucleic acid (RNA) was degraded when the cells were incubated without magnesium ${ }^{8 \sim 10\rangle}$ or incubated in the presence of ethylenediaminetetra-acetate (EDTA). ${ }^{11}$ Therefore, it can be assumed that the instability or degradation of nucleic acids due to the loss of magnesium may also occur in the sodium chloride treated cells. The present paper shows that RNA degradation is due to the action of RNase I.

\section{MATERIALS AND METHODS}

Organisms, media and cultural conditions. A thymine-requiring mutant of $E$. coli W2252 ( $\mathrm{Hfr}$, met-, $\lambda^{s}$ ) and E. coli $\mathrm{Q} 13$, a derivative of $\mathrm{RNase}_{19}$ originally isolated by Gesterand ${ }^{12)}$ (RNase $\mathrm{I}^{-}$, met $^{-}$, tyr ${ }^{-}$) were provided by Dr. Teruhiko Beppu. Cells were grown at $30^{\circ} \mathrm{C}$ with shaking in $3 \mathrm{XD}$ medium, ${ }^{13)}$ supplemented with $10 \mu \mathrm{g}$ of thymine and $50 \mu \mathrm{g}$ of methionine per $\mathrm{ml}$ for $E$. coli W2252 or with $50 \mu \mathrm{g}$ of each requring amino acid for $E$. coli Q13. An overnight culture was appropriately diluted with the same fresh medium to give the optical density at $660 \mathrm{~nm}$ of 0.3 . A portion $(0.5 \mathrm{ml})$ of the diluted culture was withdrawn and inoculated to $5 \mathrm{ml}$ of fresh $3 \mathrm{XD}$ medium with necessary nutritional additions. The culture was incubated at $30^{\circ} \mathrm{C}$ with shaking and growth was followed by the optical density at $660 \mathrm{~nm}$. Optical density measurements were done using a Hitachi FPW-4 photoelectric colorimeter. For labeling the cellular RNA of W2252, an over- 
night culture was diluted with the fresh 3XD medium supplemented with thymine and methionine to give the optical density at $660 \mathrm{~nm}$ of 0.3 . A portion $(0.5 \mathrm{ml})$ of the diluted culture was added to $5 \mathrm{ml}$ of the same medium containing $0.2 \mu \mathrm{Ci}$ of uracil-5- ${ }^{8} \mathrm{H}(18.4 \mathrm{Ci} / \mathrm{mmole}$, Daiichi Pure Chemicals Co., Ltd., Tokyo) per $\mathrm{ml}$ and was incubated for $4 \mathrm{hr}$. For the analysis of degradation products of cellular RNA, cells were labeled with $0.01 \mu \mathrm{Ci}$ per $\mathrm{ml}$ of uracil-2- ${ }^{14} \mathrm{C}(53.2 \mathrm{mCi} / \mathrm{mmole}$, Daiichi Pure Chemicals Co., Ltd., Tokyo) instead of ${ }^{8} \mathrm{H}$ uracil.

Preparation of cell suspension. Unless otherwise stated, the cells at the exponential phase of growth (optical density at $660 \mathrm{~nm}, 0.30$ to 0.35 ) were harvested by centrifugation at $8000 \times g$ for $10 \mathrm{~min}$ at room temperature, washed once with $0.01 \mathrm{~m}$ Tris (hydroxymethyl) aminomethane-hydrochloric acid buffer, $\mathrm{pH} 7.2$ (Tris buffer) and suspended in the same buffer.

Sodium chloride treatment and viabie cell counts. The washed cells were incubated at $30^{\circ} \mathrm{C}$ in Tris buffer containing $0.15 \mathrm{M}$ sodium chloride, $\mathrm{pH} 7.2(0.15 \mathrm{M}$ $\mathrm{NaCl}$-Tris buffer). A portion $(1 \mathrm{mI})$ of the suspension was withdrawn and diluted appropriately with Tris buffer at $30^{\circ} \mathrm{C}$. Immediately after the dilution, the cells $(0.2 \mathrm{ml})$ were plated on a nutrient agar medium which contained $5 \mathrm{~g}$ of meat extract (Kyokuto Seiyaku Co., Tokyo), $5 \mathrm{~g}$ of polypeptone (Daigo Eiyo Kagaku Co., Osaka), $2.5 \mathrm{~g}$ of $\mathrm{NaCl}$ and $20 \mathrm{~g}$ of agar per liter of deionized water (pH 7.0) supplemented with $10 \mu \mathrm{g} / \mathrm{ml}$ of thymine. Colonies were counted after an overnight incubation at $30^{\circ} \mathrm{C}$. The number of viable cells in each sample was calculated from an average of three independent plates.

Release of degradation products of RNA from the sodium chloride treated cells. The release of UVabsorbing materials was measured by the method of Sato $e t a l .^{3)}$ The washed cells prelabeled with ${ }^{3} \mathrm{H}-$ uracil were incubated in $0.15 \mathrm{M} \mathrm{NaCl}$-Tris buffer. At time intervals, the cells were removed by centrifugation at $8000 \times g$ for $10 \mathrm{~min}$ at $0^{\circ} \mathrm{C}$. A portion $(1 \mathrm{ml})$ of the supernatant was transferred into a glass counting vial and $1 \mathrm{ml}$ of $2.5 \%$ sodium dodecyl sulfate (SDS) was added. Radioactivity was counted by a liquid scintillation spectrometer (Horiba model LS500) using scintillation fluid of toluene-Nonion system. ${ }^{14}$ )

Degradation of RNA. The washed cells prelabeled with ${ }^{8} \mathrm{H}$-uracil were suspended in $5 \mathrm{ml}$ of Tris buffer. A portion $(0.2 \mathrm{ml})$ of the cell suspension was withdrawn and to which $0.3 \mathrm{ml}$ of Tris buffer containing $0.25 \mathrm{M}$ sodium chloride was added. Incubation was carried out at $30^{\circ} \mathrm{C}$. At time intervals, the reaction was terminated by adding an equal volume of $10 \%$ trichloroacetic acid (TCA). The precipitate was collected on a Millipore filter (HAWP, pore size $0.45 \mu$ ) and washed with $5 \%$ TCA. The filter was then dried and the radioactivity on the filter was counted by the liquid scintillation spectrometer using standard toluene system, which contained $4 \mathrm{~g}$ of PPO and $0.1 \mathrm{~g}$ of POPOP per liter of toluene.

Analysis of degradation products of RNA by paper chromatography. The washed cells, labeled with ${ }^{14} \mathrm{C}$ uracil, were incubated in $0.15 \mathrm{M} \mathrm{NaCl}$-Tris buffer for $120 \mathrm{~min}$. The degradation products of RNA were analyzed by the method of Beppu et al..$^{15)}$ The reaction mixture was cooled and TCA was added to the final concentration of $5 \%$. After extraction for $30 \mathrm{~min}$ at $5^{\circ} \mathrm{C}$ followed by centrifugation at $8000 \times g$ for $10 \mathrm{~min}$ at $0^{\circ} \mathrm{C}$, active charcoal was added to the supernatant at the concentration of $20 \mathrm{mg} / \mathrm{ml}$. The mixture was incubated and then centrifuged at $1000 \times g$ for $10 \mathrm{~min}$ at $0^{\circ} \mathrm{C}$. Charcoal was eluted with $50 \%$ ethyl alcohol containing $1 \%$ of $\mathrm{NH}_{4} \mathrm{OH}$. The extract was chromatographed on Toyo No. 50 filter paper (Toyo Roshi Co., Tokyo) with ascending using the solvent system of $n$ butyl alcohol-water-formic acid $(77: 13: 10, \mathrm{v} / \mathrm{v})$. The nucleotide fraction ( $R f=0$ to 0.1 ) was eluted from the paper and subjected to the second paper chromatography using the solvent system of isopropanol-concentrated $\mathrm{HCl}$-water $(680 \mathrm{ml}: 164 \mathrm{ml}: 160 \mathrm{ml})$ with ascending and Toyo No. 50 filter paper. 3'-Mononucleotides and $5^{\prime}$-mononucleotides were separated by the second chromatography. The paper chromatograms were scanned for radioactivity in an Aloka paper chromatogram scanner. The mononucleotides were identified by the comparison of $R f$ values of samples and authentic compounds. Finally, the paper was cut into pieces of $5 \mathrm{~mm}$ width from the origin and each pieces of the paper was counted by the liquid scintillation technique.

Preparation of crude ribosomes. The crude ribosomes were prepared by two different methods. Method 1: The washed cells, prelabeled with ${ }^{3} \mathrm{H}$-uracil, were suspended in Tris buffer containing $10 \mathrm{~mm}$ of $\mathrm{MgSO}_{4}$. The cells were disrupted by a sonic oscillator (Kubota Manufac. Co., Ltd. Tokyo) at $10 \mathrm{kHz}$ for $5 \mathrm{~min}$. The cell debris was removed by centrifugation at $18,000 \times g$ for $15 \mathrm{~min}$ at $0^{\circ} \mathrm{C}$. The supernatant fluid was again centrifuged under the same conditions. The crude ribosomes were obtained from the supernatant by centrifugation at $109,800 \times g$ for $2 \mathrm{hr}$ at $0^{\circ} \mathrm{C}$. They were washed once with Tris buffer containing $10 \mathrm{mM}$ of $\mathrm{MgSO}_{4}$ by centrifugation under the same conditions and then suspended in Tris buffer. Method 2: The washed cells prelabeled with ${ }^{3} \mathrm{H}$-uracil were suspended in $5 \mathrm{ml}$ of Tris buffer containing $20 \%$ sucrose and incubated for $5 \mathrm{~min}$ at $30^{\circ} \mathrm{C}$. To the cell suspension, $0.5 \mathrm{ml}$ of $0.017 \mathrm{M}$ Tris buffer ( $\mathrm{pH} 7.2$ ) containing $20 \%$ sucrose and $1100 \mathrm{\mu g} / \mathrm{ml}$ of lysozyme was added. After incubation of $1 \mathrm{~min}, 0.6 \mathrm{ml}$ of $0.017 \mathrm{M}$ Tris buffer containing $20 \%$ sucrose and $0.01 \mathrm{~m}$ ethylenediaminetetra-acetate 
(EDTA) was further added and incubation was continued for $14 \mathrm{~min}$ at $30^{\circ} \mathrm{C}$. The spheroplasts were harvested by centrifugation at $5000 \times g$ for $5 \mathrm{~min}$ at $0^{\circ} \mathrm{C}$. The spheroplasts were lyzed in $2.5 \mathrm{ml}$ of Tris buffer in an ice bath. The crude ribosomes were collected by centrifugation as described for Method 1.

\section{RESULTS}

Release of $U V$-absorbing materials from the cells during incubation in sodium chloride It has been reported that a significant amount of UV-absorbing materials is released from cells during incubation in sodium chloride. ${ }^{3,20}$ In keeping with this, radioactivity was released during incubation in $0.15 \mathrm{M} \mathrm{NaCl}$-Tris buffer from cells prelabeled with ${ }^{3} \mathrm{H}$-uracil. A typical result is shown in Fig. 1. The reported release

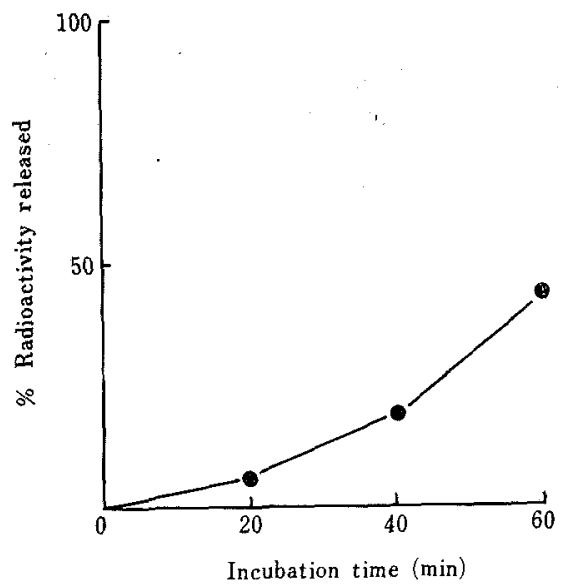

Frg. 1. Release of Degradation Products of RNA from Cells Incubated in Sodium Chloride.

The washed cells prelabeled with ${ }^{3} \mathrm{H}$-uracil were incubated in $0.15 \mathrm{M} \mathrm{NaCl}$-Tris buffer. At time intervals, the cells were harvested by centrifugation at $8000 \times g$ for $10 \mathrm{~min}$ at $0^{\circ} \mathrm{C}$. The ratio in percentage of the radioactivity released in the supernatant fluid to the total radioactivity was plotted against incubation time.

of UV-absorbing materials is the result of degradation of RNA and not of DNA, since degradation of DNA to acid soluble fraction and release of DNA from the cells were not observed during incubation in $0.15 \mathrm{M} \mathrm{NaCl}$ Tris buffer (data are not shown). After incubation of $1 \mathrm{hr}$, the release reached to approximately $40 \%$ of the total RNA. Since cell lysis was not observed during this incubation, the release of UV-absorbing materials was not due to the lysis of cells.

Degradation of $R N A$ induced by incubation in sodium chloride

The time course of RNA degradation was followed more closely. The data are shown in Fig. 2. There was a lag time of about $20 \mathrm{~min}$ before the onset of degradation of RNA. The amount of RNA degraded increased with incubation time and approximately $50 \%$ of RNA was degraded after incubation of $2 \mathrm{hr}$. Similar results were obtained with other monovalent cations such as $\mathrm{KCl}$ or $\mathrm{LiCl}$ instead of $\mathrm{NaCl}$ at the same concentrations (data are not shown).

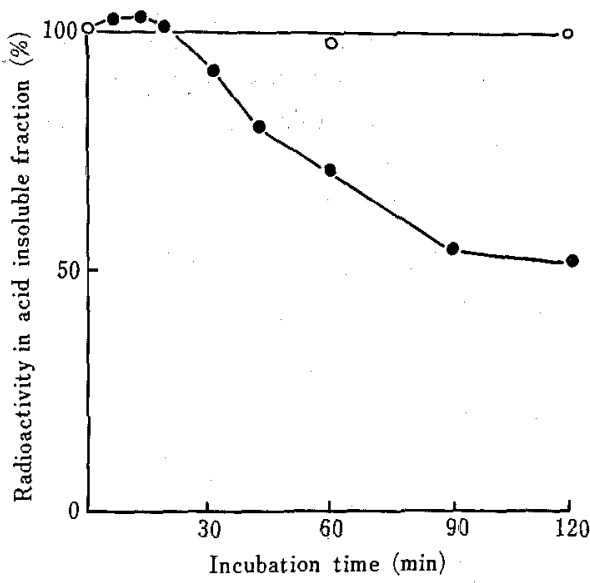

FIG. 2. Degradation of RNA Induced by Sodium Chloride Treatment.

The washed cells prelabeled with ${ }^{8} \mathrm{H}$-uracil were incubated in $0.15 \mathrm{M} \mathrm{NaCl}$-Tris buffer or $0.01 \mathrm{M}$ Tris buffer. At time intervals, the reaction was stopped by the addition of TCA (final $5 \%$ ) at $0^{\circ} \mathrm{C}$. The percentage of the radioactivity remained in the acid insoluble fraction was plotted against incubation time. $O$, control, which was incubated in plain Tris buffer; , incubated in $0.15 \mathrm{M} \mathrm{NaCl}$-Tris buffer.

Effect of concentrations of sodium chloride on degradation of $R N A$

As shown in Fig. 3, the degradation of RNA increased with increasing concentrations of sodium chloride up to $0.15 \mathrm{M}$. The relationship between the concentrations of sodium chloride and the extent of RNA degradation was similar to that between the concentrations 


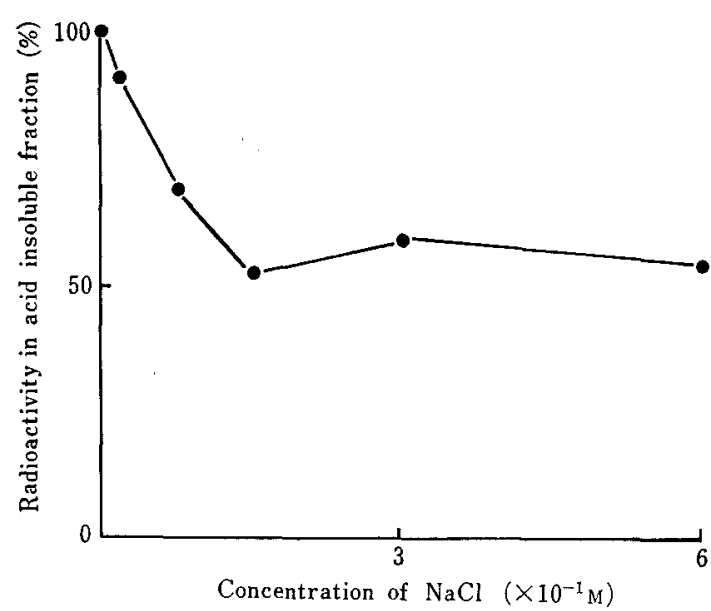

FIG. 3. Effect of Sodium Chloride Concentrations on RNA Degradation.

The washed cells prelabeled with ${ }^{3} \mathrm{H}$-uracil were incubated in $0.01 \mathrm{M}$ Tris buffer containing various concentrations of sodium chloride for $2 \mathrm{hr}$. The degradation of RNA was determined under the same conditions as in Fig. 2 and was plotted against sodium chloride concentrations.

of sodium chloride and the loss of viability (See reference 3, Fig. 1).

\section{Protective effect of magnesium on RNA degradation induced by sodium chloride}

It has been shown in the previous paper that the presence of magnesium ion in sodium chloride protected cells from the lethal effect. As shown in Fig. 4, the addition of magnesium ion to $0.15 \mathrm{M} \mathrm{NaCl}$-Tris buffer inhibited the degradation of RNA almost immediately and completely. Since the extent of RNA degradation induced by the sodium chloride treatment was extensive, and it is known that the bulk of RNA is ribosomal, the crude ribosomes were prepared from $E$. coli W2252 and was treated with sodium chloride in vitro. As shown in Fig. 5, the ribosomal RNA was rapidly degraded during incubation in sodium chloride and the degradation was protected by the addition of magnesium. It is known that magnesium stabilizes the ribosomes ${ }^{17)}$ and the release of magnesium occurs during incubation of whole cells in sodium chloride. ${ }^{2)}$ Therefore, the loss of magnesium from the cells may induce the degradation of ribosomal RNA.

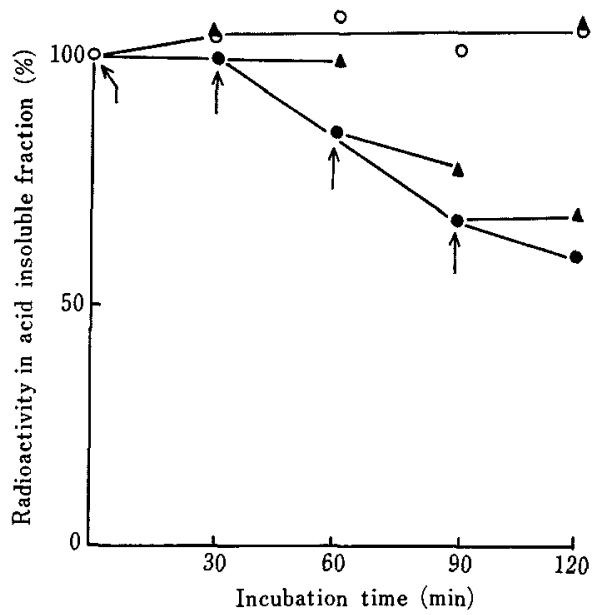

Fig. 4. Protective Effect of Magnesium on RNA Degradation Induced by Sodium Chloride.

The conditions of sodium chloride treatment was the same as described in Fig. 2 except that the addition of magnesium was made to the cell suspension.

0 , control, incubated in Tris buffer; $\bullet$, incubated in $0.15 \mathrm{M} \mathrm{NaCl}$-Tris buffer; $\Delta$, incubated in $0.15 \mathrm{M} \mathrm{NaCl}-$ Tris buffer but was added $50 \mathrm{~mm}$ of $\mathrm{MgSO}_{4}$ at the time indicated by arrows.

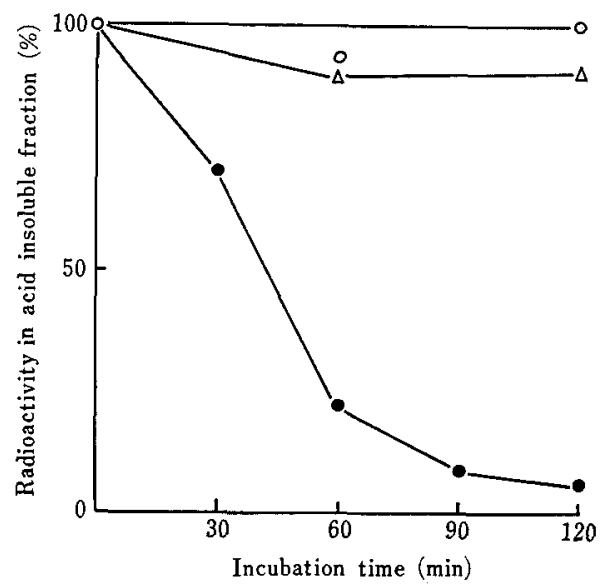

FIG. 5. Degradation of RNA in Ribosomes Induced by Sodium Chloride in vitro.

The degradation of RNA was determined under the same conditions as shown in Fig. 2 except that crude ribosomes obtained by sonic disruption were used instead of washed cells.

$O$, control, incubated in Tris buffer; $\boldsymbol{\bullet}$, incubated in $0.15 \mathrm{M} \mathrm{NaCl}$-Tris buffer; $\triangle$, incubated in $0.15 \mathrm{M} \mathrm{NaCl}$ Tris buffer containing $5 \mathrm{~mm}$ of $\mathrm{MgSO}_{4}$.

Analysis of the degradation products of RNA By analyzing mononucleotides formed from RNA, it is possible to know what kind of ribo- 


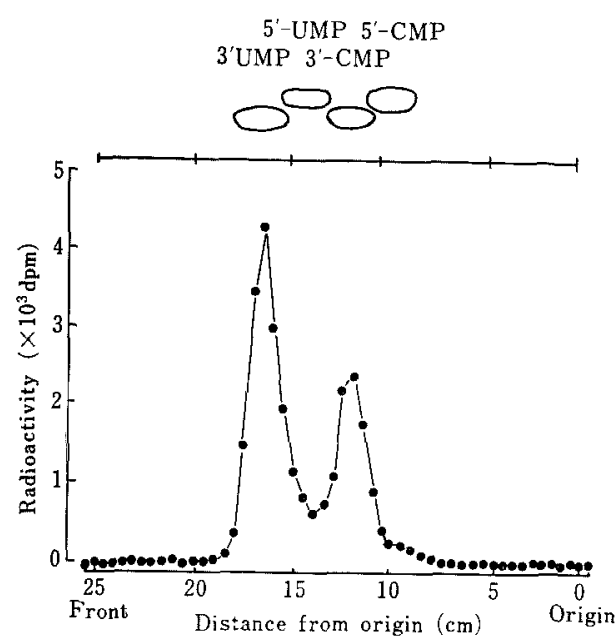

Fig. 6. Analysis of Degradation Products of RNA. The lower figure shows distribution of radioactivity of second paper chromatogram. The upper figure shows position of each standard nucleotides under the same conditions.

nuclease (RNase) is activated in the cells by the sodium chloride treatment. Therefore, the degradation products of RNA induced by the sodium chloride treatment were analyzed by paper chromatography. As shown in Fig. 6, two radioactive peaks were separated which were identified as $3^{\prime}$-uridine monophosphate and 3 -cytidine monophosphate, respectively. The formation of $3^{\prime}$ - but not 5'-mononucleotides suggests the involvement of RNase $\mathbf{I}^{18 \text { ) }}$ in this degradation.

\section{Absence of $R N A$ degradation in E. coli $Q 13$}

In order to examine the possible role of RNase $I$ in this degradation of RNA induced by the sodium chloride treatment, the experiment using $E$. coli $\mathrm{Q} 13$ (RNase $\mathrm{I}^{-}$) was performed. As shown in Fig. 7, both the degradation of RNA in sodium chloride and the decrease in viability in the sodium chloride osmotic shock did not occur in this strain. On the other hand, both the degradation of RNA and the decrease of survivals occurred in $E$. coli W2252, which is normal in RNase I. These results suggest that the degradation of RNA induced by the sodium chloride treatment is due to the action of RNase I and this degradation is one of the injuries induced by sodium

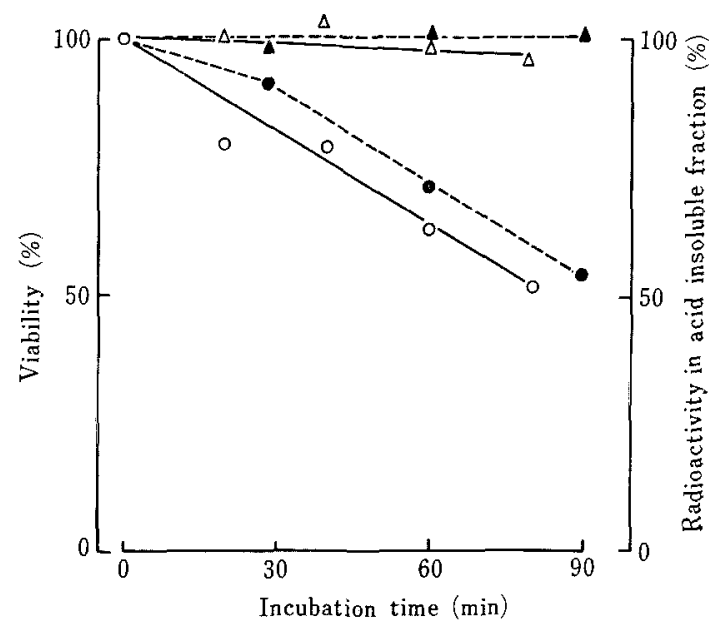

Fig. 7. Relationship between RNA Degradation and Loss of Viability by Sodium Chloride Treatment in $E$. coli W2252 and Q13.

The degradation of RNA was determined under the same conditions as shown in Fig. 2. Viability was estimated by plating out $\mathrm{NaCl}$-treated cells on nutrient agar plate after dilution and incubation for $5 \mathrm{~min}$.

$O$, viability of $E$. coli $\mathrm{W} 2252$, incubated in $0.15 \mathrm{M}$ $\mathrm{NaCl}$-Tris buffer; $\triangle$, viability of $E$. coli $\mathrm{Q} 13$, incubated in $0.15 \mathrm{M} \mathrm{NaCl}$-Tris buffer, degradation of RNA in $E$. coli W2252, incubated in $0.15 \mathrm{M} \mathrm{NaCl-Tris} \mathrm{buffer;}$ $\Delta$, degradation of RNA in $E$. coli $\mathrm{Q} 13$, incubated in $0.15 \mathrm{M} \mathrm{NaCl}$-Tris buffer.

chloride.

RNA degradation in ribosomes prepared by two different methods

It is known that RNase I is localized in a periplasmic space ${ }^{19}$ ) and it also occurs in an inactivated form bound to $30 \mathrm{~s}$ subunits of ribosomes after cell disruption. ${ }^{20,21)}$ When cells are disrupted under drastic conditions such as sonic oscillation, RNase I seems to be liberated from the cell envelope and is bound to 30 s subunits of ribosomes. However, since RNase I is known to be liberated from cells during the formation of spheroplasts, ${ }^{19)}$ most of the ribosomes obtained by such mild procedures appear to be free from RNase I. Therefore, ribosomes, which were obtained by two different procedures, sonic disruption and osmotic shock of the spheroplasts, were compared each other with respect to their susceptibilities to 


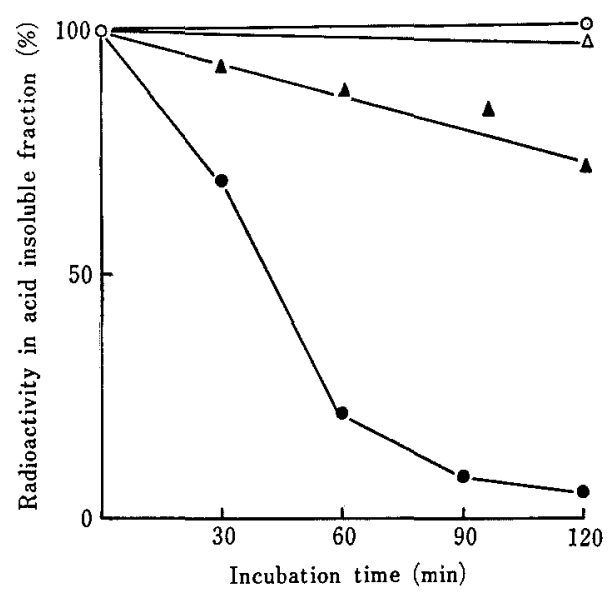

FIG. 8. The Degradation of RNA in Crude Ribosomes Prepared by Two Different Methods.

The degradation of RNA was determined under the same conditions as described in Fig. 2 except that crude ribosomes obtained by two different methods were used instead of washed cells.

$O$, crude ribosomes obtained by sonic disruption, incubated in Tris buffer; $\bullet$, crude ribosomes as above, incubated in $0.15 \mathrm{M} \mathrm{NaCl}$-Tris buffer; $\triangle$, crude ribosomes obtained by osmotic shock of spheroplasts, incubated in Tris buffer; $\mathbf{\Lambda}$, crude ribosomes as above, incubated in $0.15 \mathrm{M} \mathrm{NaCl}$-Tris buffer.

the sodium chloride treatment. As shown in Fig. 8, RNA in the ribosome fraction obtained by the sonic treatment was rapidly degraded during incubation in sodium chloride, but degradation of RNA in the ribosomes obtained by the osmotic shock of the spheroplasts proceeded much more slowly. From these results, it may be said that two separate processes seem to be involved in the action of sodium chloride, one is the translocation of RNase I from the periplasmic space to cytoplasm, and the other is the degradation of ribosomal RNA by RNase I.

\section{Degradation of RNA of sodium chloride treated cells after osmotic shock}

In a previous paper, ${ }^{1}$ it was shown that the viability of the cells was maintained during incubation in sodium chloride and was rapidly lost by the following dilution process. In other words, some injuries induced by sodium chloride are still reversibly repaired but become unable to be repaired after the dilution process.
In this connection, we have examined the effect of the osmotic shock on RNA degradation. As shown in Fig. 9, when cells were treated with $0.15 \mathrm{M} \mathrm{NaCl}$-Tris buffer and resuspended in the same buffer, the RNA degradation proceeded further, while when they were shocked osmotically in $0.01 \mathrm{M}$ Tris buffer after sodium chloride treatment, the degradation of RNA occurred with much reduced rate. These results suggest that the degradation of RNA is not the lethal reaction in itself, and a different lethal reaction should be involved in the osmotic shock.

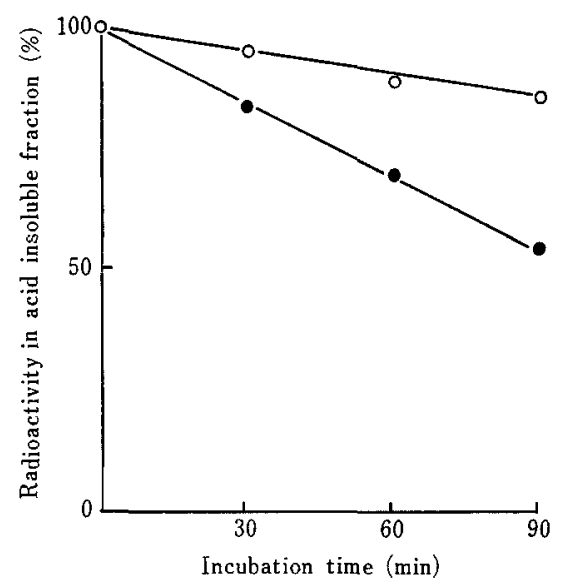

FIG. 9. Degradation of RNA of Sodium Chloride Treated Cells after Osmotic Shock.

The cells, suspended in $0.15 \mathrm{M} \mathrm{NaCl}$-Tris buffer $(5 \mathrm{ml})$ were harvested by centrifugation at $8000 \times g$ for $10 \mathrm{~min}$ at $0^{\circ} \mathrm{C}$. They were resuspended in $2.5 \mathrm{ml}$ of $0.01 \mathrm{M}$ Tris buffer in an ice bath. To this cell suspension $(0.2 \mathrm{ml})$ was added $0.3 \mathrm{ml}$ of $0.01 \mathrm{M}$ Tris buffer or the same buffer containing $0.25 \mathrm{M}$ sodium chloride. Incubation was continued at $30^{\circ} \mathrm{C}$. Time course of RNA degradation during incubation was followed under the same condition as shown in Fig. 2.

$O$, incubated in Tris buffer; $\odot$, incubated in $0.15 \mathrm{M}$ $\mathrm{NaCl}-\mathrm{Tr}$ is buffer.

\section{DISCUSSION}

It has been clearly demonstrated in this experiment that the degradation of RNA was induced during incubation of $E$. coli cells in sodium chloride. This degradation seemed to be due to the action of RNase I from the following reasons. 1) The degradation of RNA did not occur in $E$. coli Q13, which is deficient in RNase I activity. 2) 3'-Mono- 
nucleotides but not $5^{\prime}$-mononucleotides were found as the degradation products. Since the degradation of RNA stopped immediately on addition of magnesium either in vivo or in vitro with crude ribosomes, the degradation of RNA induced by sodium chloride is due to the loss of magnesium from the cells. This hypothesis is supported by the observation that the release of magnesium from the cells occurs during incubation in sodium chloride, ${ }^{2)}$ and magnesium is known to stabilize ribosomes. Two types of degradation of RNA induced by the loss of metal ions have been reported..$^{8 \sim 10)}$ One is the degradation of RNA induced by the EDTA treatment and the other is the one observed in cells grown in a magnesium deficient medium. Both of them, however, were observed with $E$. coli Q13. Since the degradation of RNA induced by the sodium chloride treatment did not occur in $E$. coli Q13, the nature of the degradation of RNA observed in this experiment is different from those of two other types.

RNase I is known to be a periplasmic enzyme and it remains as an inactive form bound to the 30 s subunits of ribosomes in the broken cell preparations. The fact that the cellular RNA was degraded by RNase I during incubation in sodium chloride indicates that the translocation of RNase I may occur at the first stage, and then the cellular RNA, mainly ribosomal RNA, was degraded by either the activation of the enzyme itself or the unstable nature of the ribosomes. These hypothesis are supported by the fact that about $90 \%$ of RNase I activity is released during the formation of spheroplasts, ${ }^{19)}$ and the ribosomes prepared by this method was slowly degraded in sodium chloride. Although we have no evidence at the present time, it is possible to consider that the structural changes of the membrane induced by the loss of magnesium may result in the translocation of RNase I. The lag time, which was observed prior to the initiation of RNA degradation, might be required for the changes of membrane structures.

Since it has been known that the cells of wild type, which are incubated in sodium chloride and whose RNA is degraded to the extent of
$50 \%$ or more, are still viable when they are plated out without the osmotic shock, it is clear that the degradation of RNA is not lethal by itself. It could be understood that the cells of $E$. coli Q13 were resistant to the sodium chloride treatment with regard to the RNA degradation. However, it was an unexpected finding that they are resistant to the sodium chloride osmotic shock as measured by viabilities. At present, we have no explanation for this result. Anyhow, the lethal reaction occurs at the osmotic shock process. Further studies are needed to understand the lethal effect of the sodium chloride osmotic shock.

Acknowledgement. We are grateful to Dr.T. Beppu, Department of Agricultural Chemistry, The University of Tokyo, for his generous supply of $E$. coli $\mathrm{W} 2252$ and Q13.

\section{REFERENCES}

1) K. Ito, K. Nakamura, K. Izaki and H. Takahashi, Agric. Biol. Chem., 41, 253 (1977).

2) T. Sato, Y. Suzuki, K. Izaki and H. Takahashi, J. Gen. Appl. Microbiol., 17, 371 (1971).

3) T. Sato, K. Tzaki and H. Takahashi, ibid., 18, 307 (1972).

4) M. Sato and H. Takahashi, ibid., 14, 417 (1968).

5) M. Sato and H. Takahashi, ibid., 15, 217 (1969).

6) M. Sato and H. Takahashi, ibid., 15, 483 (1969).

7) M. Sato and H. Takahashi, ibid., 16, 279 (1970).

8) B. J. MacCarthy, Biochim. Biophys. Acta, 55, 880 (1962).

9) H. Maruyama and D. Mizuno, ibid, 199, 166 (1970).

10) S. Natori, R. Nozawa and D. Mizuno, ibid., 114, 245 (1966).

11) H. C. Neu, D. F. Ashman and T. D. Price, J. Bacteriol., 93, 1360 (1967).

12) R. F. Gesteland, Fed. Proc., 24, 293 (1965).

13) D. Frazer and E. A. Jerrel, I. Biol. Chem., 205, 291 (1953).

14) M. Kawakami and K. Shimura, Radioisotope, 23, 81 (1974).

15) T. Beppu and K. Arima, J. Bacteriol., 98, 888 (1969).

16) T. Iijima and Y. Ikeda, J. Gen. Appl. Microbiol,, 15, 453 (1969).

17) R. F. Gesteland, J. Mol. Biol., 18, 356 (1966).

18) P. E. Spahr and B. R. Hollingworth, J. Biol. Chem., 236, 823 (1961).

19) H. C. Neu and L. A. Heppel, ibid, 239, 3893 (1964).

20) H. E. Wada and H.K. Robinson, Biochem. J., 97, 747 (1965).

21) Y. Anraku and D. Mizuno, J. Biochem., 61, 70 (1967). 